\title{
DIARRHEA OUTBREAK IN PERNAMBUCO, BRAZIL, ASSOCIATED WITH A HEAT-STABLE CYTOTOXIC ENTEROTOXIN PRODUCED BY Aeromonas caviae
}

\author{
Ana Carolina Amaral LOPES(1), Luciano Moura MARTINS(2), Maria SilviaViccari GATTI(1) Cristhiane Moura FALAVINA DOS REIS(3), \\ Ernesto HOFER(3) \& Tomomasa YANO (1)
}

\begin{abstract}
SUMMARY
In the present study enterotoxic and cytotoxic activities of twenty Aeromonas caviae strains were examined. They originated from fecal specimens of patients with acute diarrhea during an outbreak in Brazil in 2004. Culture supernatants of fourteen strains (70\%) caused fluid accumulation in rabbit ileal intestinal loops and in suckling mice assays, and also showed a cytotoxic activity in Vero and Caco- 2 cells. The enterotoxic and cytotoxic factors were heat-stable after culture supernatants treatment at $100{ }^{\circ} \mathrm{C}$. The results revealed that $A$. caviae strains produce a putative diarrheagenic virulence factor, a heat-stable cytotoxic enterotoxin that could be linked to the diarrhea outbreak that took place in Brazil.
\end{abstract}

KEYWORDS: Diarrhea outbreak; Aeromonas caviae; Cytotoxic enterotoxin; Virulence factors.

\section{INTRODUCTION}

Aeromonas spp. are Gram-negative rods that belong to the Aeromonadaceae family, which are widely spread across nature and can be found in a great variety of places including salt and drinking water, soil, sewage systems and uncooked or refrigerated foods ${ }^{6}$. Aeromonas is considered to be a common pathogen of fishes and following the 1970s these microorganisms have also been considered to be human pathogens $s^{8,13}$. Acute diarrheal disease after the ingestion of contaminated water and food is common in many countries ${ }^{9}$. The virulence factors produced by these species, such as enterotoxins, hemolysins, cytotoxins, and adhesins, are the main determinants of human enteropathological processes $^{6}$.

In 2004, there was an outbreak of acute diarrhea in Sao Bento do Una, Pernambuco State, Brazil ${ }^{5}$, in which V. cholerae $\mathrm{O} 1$ and Aeromonas ssp. in ISR $16 \mathrm{~S}-23 \mathrm{~S}$ and RAPD amplification were recovered; all $V$. cholerae revealed homogeneous profiles and presence of potential virulence genes, however, it was observed that Aeromonas spp. were highly heterogeneous. It was concluded, then, that $V$. cholerae $\mathrm{O} 1$ was probably the responsible agent for the diarrhea outbreak. Nevertheless, the participation of Aeromonas was not ruled out ${ }^{11}$.

Therefore, the present study aimed to verify the possible diarrheagenic virulence factors of A. caviae, because it is the most prevalent specie (ca. $41 \%$ ) of all the isolated Aeromonas spp. ${ }^{11}$.
Twenty A. caviae were cultivated in Müller Hinton broth (Difco Lab. USA) with the aid of a shaker, at $37^{\circ} \mathrm{C}$ for $16 \mathrm{~h}$. The culture supernatants were analyzed for enterotoxic activity by the suckling mice assay ${ }^{1}$. Three neonatal Balb/C mice, two to four- days-old, were used for each sample. A $50 \mu \mathrm{L}$ volume of each sample was administered to each mouse, intragastrically. After three hours, the mice were executed following recommended procedures and the whole intestines were removed. Both the intestines and remaining corpse were weighed to calculate the ratio between the intestines (I) and the remaining corpse (B): I/B. Assays were performed in sets of three. Results were considered positive when the ratio results were $\geq 0.09^{1}$.

Additionally, a rabbit intestinal loop test ${ }^{2}$ was conducted using white adult male New Zealand rabbits weighing $1.5-2.0 \mathrm{~kg}$. The intestinal lumen was rinsed three times with saline solution, then, series of intestines were exteriorized through a midline incision; ligated intestinal segments (loops) of about $5 \mathrm{~cm}$ of length, separated by a 1 to $2 \mathrm{~cm}$ interloop. Each loop was filled with $1 \mathrm{~mL}$ of the sample solution. A control loop injected with sterile culture medium was included. Rabbits were maintained for $18 \mathrm{~h}$ at room temperature following euthanasia. The fluid accumulation in the intestinal loops was measured as the ratio between the weight of the loop (in grams) and length (in centimeters). Ratio results $>0.2$ were regarded as a positive response ${ }^{2}$. The assays were performed in sets of three. Sterile culture medium (Müller Hinton broth) was used as a negative control loop and the positive control was the cultured supernatant of $A$. veronii biovar sobria AS $31^{10}$.

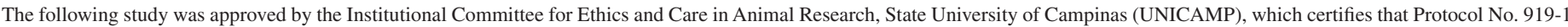
is in agreement with the Ethical Principles for Animal Research established by the Brazilian College for Animal Experimentation (COBEA).

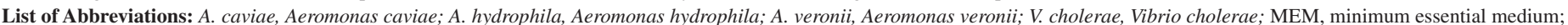
FBS, fetal bovine serum.

(1) Genetics, Evolution and Bioagents Department, State University of Campinas (UNICAMP), Campinas, SP, Brazil.

(2) Center of Bacteriology, Enteric and Special Pathogens Infectious Diseases Department, Instituto Adolfo Lutz, Sao Paulo, SP, Brazil.

(3) Bacteriology Department, Instituto Oswaldo Cruz, Fundação Oswaldo Cruz, Rio de Janeiro, RJ, Brazil.

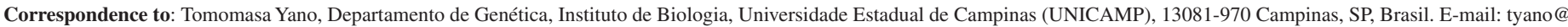
unicamp.br 
LOPES, A.C.A.; MARTINS, L.M.; GATTI, M.S.V.; FALAVINA DOS REIS, C.M.; HOFER, E. \& YANO, T. - Diarrhea outbreak in Pernambuco, Brazil, associated with a heat-stable cytotoxic enterotoxin produced by Aeromonas caviae. Rev. Inst. Med. Trop. Sao Paulo, 57(4): 349-51, 2015.

The culture supernatants that were positive in the suckling mice assay, meaning $70 \%$ (14 of 20), were also positive in the rabbit intestinal loop test $^{2}$, confirming the enterotoxic activity of $A$. caviae isolates.

The cytotoxic activity of $A$. caviae culture supernatants was detected as described ${ }^{7}$ in Vero (African green monkey kidney), Caco-2 (human intestinal carcinoma), HeLa (human uterus carcinoma) and HEp-2 (human larynx carcinoma) (ATCC, Rockville, MD, USA) cell lines cultivated in tissue culture flasks with Eagle's minimum essential medium (MEM, Nutricell, Campinas, SP, Brazil) supplemented with $10 \%(\mathrm{v} / \mathrm{v})$ of fetal bovine serum (FBS). The filter-sterilized culture supernatants were inoculated in a confluent monolayer (serial two fold dilutions). Then, the plates were incubated at $37{ }^{\circ} \mathrm{C}$ in a $5 \% \mathrm{CO}_{2}$ chamber. The culture filtrates of A. sobria AS-69, a non cytotoxin-producing strain ${ }^{10}$, and MEM medium were used as negative controls. Cell monolayer morphology was observed using an inverted microscope.

The same A. caviae culture supernatants, in which enterotoxic activity was observed, induced morphological alterations in Vero and Caco-2 cells after three hours of culture filtrates inoculation, inducing cellular elongation, rounding, loosening of intercellular junctions and detachment were observed, leading to cellular death (Fig.1). These observations resemble those previously described ${ }^{4}$, in which bacterial suspensions of A. hydrophila, A. veronii biovar sobria and A. caviae were assayed in cultured Vero and $\mathrm{CHO}$ cells. Despite the similarities of the cytotoxic effects, injuries and destruction induced on cells, we observed that the cytotoxin present in our samples was found free in the cultured supernatants.

The cytotoxic and enterotoxin activities of the A. caviae culture supernatants were not affected by heat treatment at $60{ }^{\circ} \mathrm{C}$ and $100{ }^{\circ} \mathrm{C}$ for $15 \mathrm{~min}$. These assays demonstrated that the cytotoxic-enterototoxic activity produced by these $A$. caviae is heat-stable.

The description of a heat-stable cytotoxic activity produced by A. caviae in HEp-2 cells has already been described ${ }^{12}$, but our culture supernatants did not exhibit cytotoxic effects on HEp-2 or HeLa cells (data not shown). The most intense effects were observed in Caco-2 cells, a human intestinal cell lineage, reinforcing its specific activity in intestinal cells in these in vitro assays.

Therefore, this work reveals the expression of a heat-stable cytotoxic
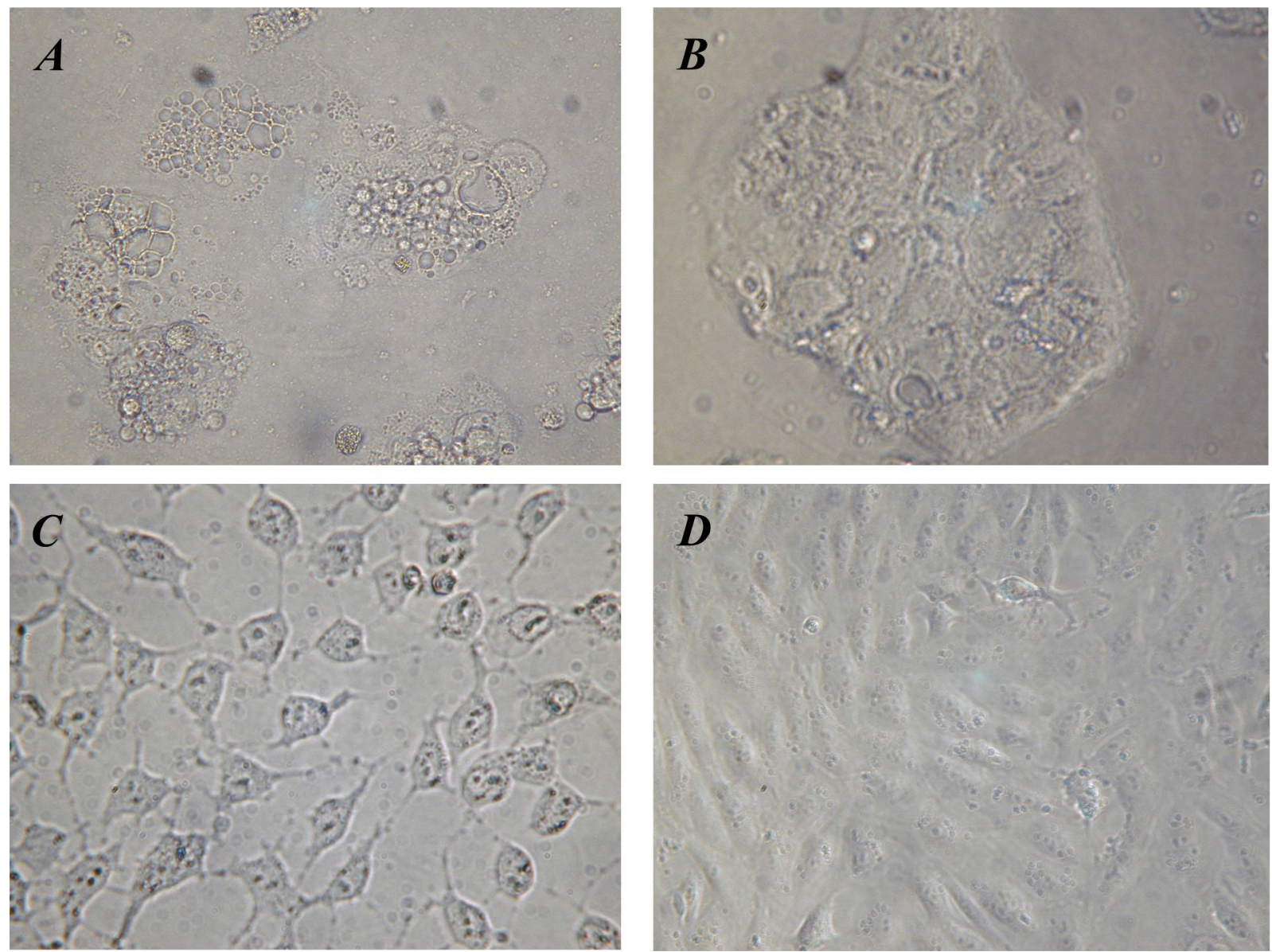

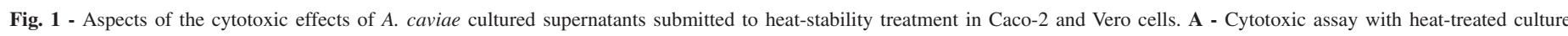

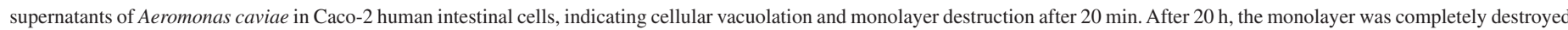

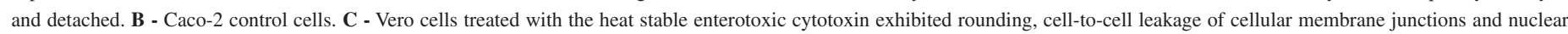
condensation. D - Vero control cells. Magnifications 430X. 


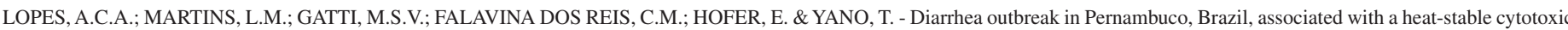
enterotoxin produced by Aeromonas caviae. Rev. Inst. Med. Trop. Sao Paulo, 57(4): 349-51, 2015.

enterotoxin by A. caviae that could be associated with the diarrhea outbreak that took place in Pernambuco, Brazil. It could be a new diarrheagenic virulence factor not yet described among the Aeromonas species. The purification of this heat-stable cytotoxic enterotoxin is currently being conducted to identify its chemical nature, aiming to elucidate its role in the enteropathogenic activities induced by A. caviae.

\section{RESUMO}

\section{O surto de diarreia em Pernambuco, Brasil é associado com uma enterotoxina citotóxica termo-estável produzida por Aeromonas caviae}

Em 2004 ocorreu um surto de diarreia aguda no Estado de Pernambuco, Brasil. Setenta por cento (14 dos 20) dos sobrenadantes de cultura de Aeromonas caviae, isoladas neste episódio induziram acúmulo de líquido em testes de alça ligada de intestino de coelhos, assim como em teste em camundongos recém-nascidos. Os mesmos sobrenadantes mostraram também atividade citotóxica em células de Vero e Caco-2, mas não em células HeLa e HEp2. As atividades enterotóxicas e citotóxicas mantiveram-se mesmo após o aquecimento a $100{ }^{\circ} \mathrm{C}$ dos sobrenadantes de cultura. Este trabalho revela a expressão de um provável fator diarreiogênico: uma enterotoxina-citotóxica termo-estável, produzida por A. caviae que pode ser associada ao surto de diarreia ocorrido no Brasil. Atualmente estamos purificando esta enterotoxina termo-estável, com o objetivo de elucidar seu papel como fator de virulência na diarreia causada por A. caviae.

\section{ACKNOWLEDGMENTS}

We thank Ana Stella Menegon Degrossoli for technical support and the Fundação de Amparo à Pesquisa do Estado de São Paulo (FAPESP), for financial support.

\section{DISCLOSURE}

The authors have no conflicts of interest to declare.

\section{REFERENCES}

1. Dean AG, Ching YC, Williams RG, Harden LB. Test for Escherichia coli enterotoxin using infant mice: application in a study of diarrhea in children in Honolulu. J Infect Dis. 1972;125:407-11.
2. Evans DG, Evans DJ Jr, Pierce NF. Differences in the response of rabbit small intestine to heat-labile and heat-stable enterotoxins of Escherichia coli. Infect Immun. $1973 ; 7: 873-80$

3. Freitas AC, Souza SM, Macedo LC, Pinto EC, Pereira SS. Aeromonas species associated with gastroenteritis in children: prevalence, characteristics and virulence properties. Rev Microbiol. 1998;29:152-7.

4. Fujii Y, Nomura T, Kanzawa H, Kameyama M, Yamanaka H, Akita M, et al Purification and characterization of enterotoxin produced by Aeromonas sobria. Microbiol Immun. 1998;42:703-14.

5. Hofer E, Reis CM, Theophilo GN, Cavalcanti VO, Lima NV, Henriques MF Envolvimento de Aeromonas em surto de doença diarréica aguda em São Bento do Una, Pernambuco. Rev Soc Bras Med Trop. 2006;39:217-20.

6. Janda JM, Abbott SL. The genus Aeromonas: taxonomy, pathogenicity and infection Clin Microbiol Rev. 2010;23:35-73

7. Konowalchuk J, Spiers JI, Stravic S. Vero response to a cytotoxin of Escheriichia coli. Infect Immun. 1977;18:775-9.

8. Krovacek K, Faris A, Baloda SB, Peterz M, Lindberg T, Mansson I. Prevalence and characterization of Aeromonas spp. isolated from foods in Uppsala, Sweden. Food Microbiol. 1992;9:29-36.

9. Kuhn I, Albert MJ, Ansaruzzaman M, Bhuiyan NA, Alabi SA, Islam MS, et al Characterization of Aeromonas spp. isolated from humans with diarrhea, from healthy controls, and from surface water in Bangladesh. J Clin Microbiol. 1997;35:369-73.

10. Martins LM, Catani CF, Falcón RM, Carbonell GV, Azzoni AA, Yano T. Induction of apoptosis in Vero cells by Aeromonas veronii biovar sobria vacuolating cytotoxic factor. FEMS Immun Med Microbiol. 2007;49:197-204.

11. Mendes-Marques CL, Nascimento LM, Theophilo GN, Hofer E, Melo Neto OP, Leal NC. Molecular characterization of Aeromonas spp. and Vibrio cholerae isolated during a diarrhea outbreak. Rev Inst Med Trop Sao Paulo. 2012;54:299-304.

12. Namdari H, Bottone EJ. Cytotoxin and enterotoxin production as factors delineating enteropathogenicity of Aeromonas caviae. J Clin Microbiol. 1990;28:1796-8.

13. Pedroso DM, Iaria ST, Cerqueira-Campos ML, Heldtmann S, Rall VL, Pimenta $\mathrm{F}$, et al. Virulence factors in motile Aeromonas spp. isolated from vegetables. Rev Microbiol. 1997;28:49-54.

Received: 23 July 2014

Accepted: 3 November 2014 


\section{LIBRARY OF THE \\ SÃO PAULO INSTITUTE OF TROPICAL MEDICINE}

Website: http://www.imt.usp.br/sobre-o-imtsp/biblioteca

Address: Biblioteca do Instituto de Medicina Tropical de São Paulo da Universidade de São Paulo Av. Dr. Enéas de Carvalho Aguiar, 470.

05403-000 - São Paulo - SP - Brazil.

Telephone: 5511 3061-7003
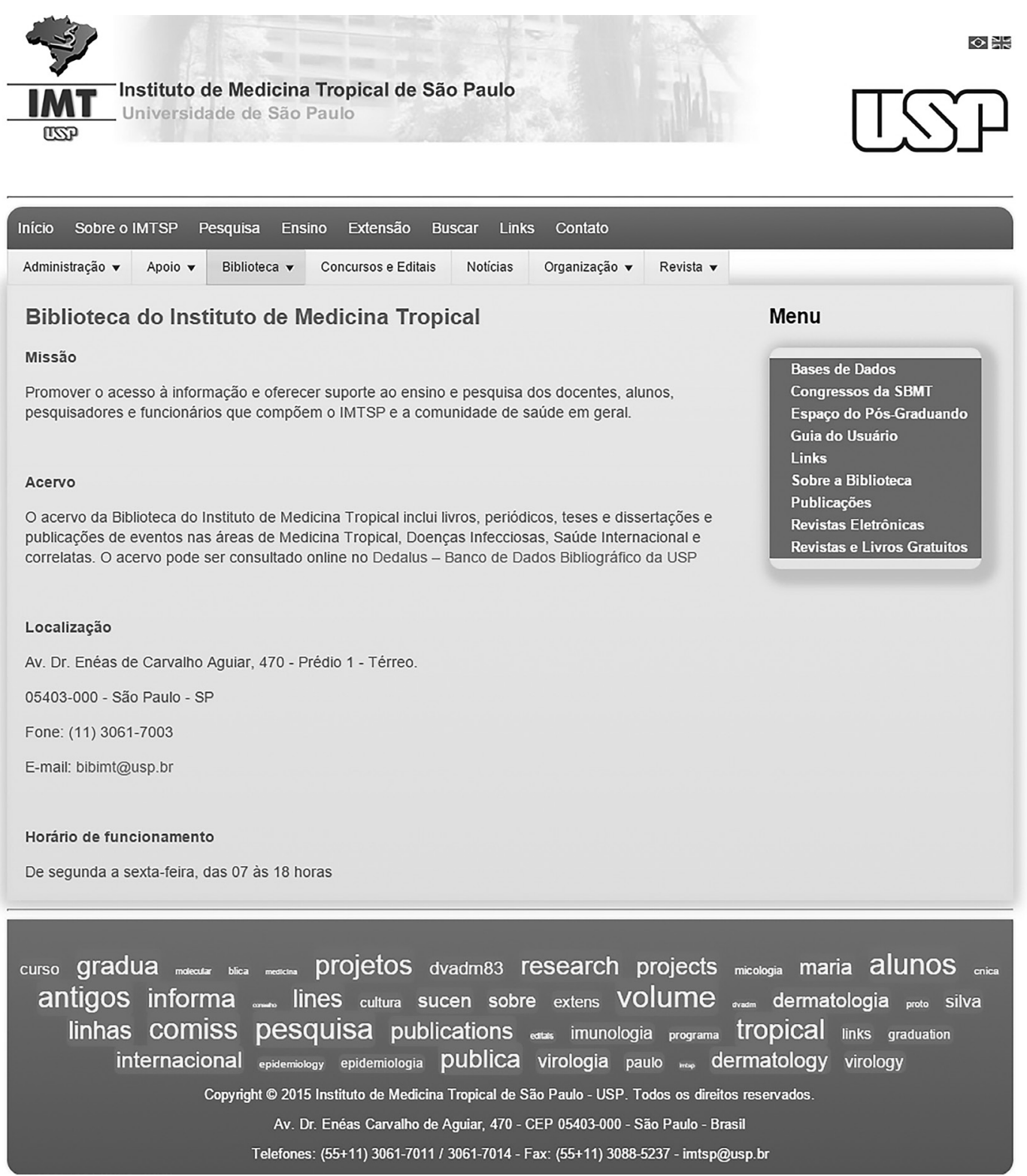

The Library of the São Paulo Institute of Tropical Medicine (IMTSP Library) was created on January 15, 1959 in order to serve all those who are interested in tropical diseases.

The IMTSP Library has a collection consisting of books, theses, annals of congresses, journals, and reference works.

The collection of the Library can be searched through the USP Bibliographic Database - Dedalus at the URL http://200.144.190.234/F 